\title{
WHO'S GOT THE POWER? YOUNG CHILDREN'S POWER AND AGENCY IN THE CHILD-PARENT RELATIONSHIP
}

\author{
Eija Sevón
}

\begin{abstract}
Children's rights and their increasing voice in families have made relations between parents and children more democratic. Despite this, child-parent relationships have been claimed to be relationships between unequals from the perspective of power. Often, power is understood as top-down with parents as wielders of power over their children and children as recipients of parental demands. The generational ordering of relations between children and adults poses the challenge of how to conceptualize power in the child-parent relationship, and how methodologically to study power and children's agency, in particular, from the viewpoint of young children. This study explored in what ways power and young children's agency become visible in power struggles and negotiations in the childparent relationship. The participants were 18 Finnish 4- to 7-year-old children. The data consisted of episodes of challenging situations in the child-parent relationship collected via a multi-method approach. In these episodes, power was related to parental authority and child compliance, but also to the child's possibilities for agency via many forms of resistance and accommodation. Young children's agency can be seen as connected to the opportunity to resist, to participate in the negotiation of power, and so to influence and evoke change in the child-parent relationship.
\end{abstract}

Keywords: agency, child-parent relationship, compliance, power, resistance, young children

Acknowledgement: This research was supported in part by the Academy of Finland (Grant 137959).

Eija Sevón, PhD, is a researcher in the Faculty of Educational Sciences, Department of Education, P.O. Box 35, 40014 University of Jyvaskyla, Finland. E-mail: eija.sevon@jyu.fi 
Diminished parental authority, the current idea that children have a right to participate and "have a say" in matters concerning them, has affected the child-parent relationship making it more democratic (Bjerke, 2011; Punch, 2005; van Nijnatten, 2010, pp. 52-54). However, the traditional research approaches to child-parent relations have continued to focus on how carers and their parental practices affect children, and have tended to view parents as active agents and children as passive recipients of parental actions (De Mol \& Buysse, 2008; Kuczynski \& Navara, 2006). The relationship then is seen as strictly topdown, from parent to child, meaning that the child's influence and agency are not recognized (De Mol \& Buysse, 2008). Accordingly, from the perspective of power, the child-parent relationship has been regarded as a relationship between unequals (see Cockburn, 2010; Merry, 2007; Punch, 2005). Power is often understood as parental authority, that is, parents wielding power and control over their children and children complying with parental demands (Kuczynski, 2003; Kuczynski \& Parkin, 2007; Punch, 2005; Rainio, 2008). Generally, not much is known about this relationship from the perspective of the "cared for", the children themselves (Cockburn, 2010). Consequently, the question of power in the childparent relationship and, in particular, how parental control and demands are understood, received, and resisted by young children, is an important area of study.

This paper adheres to the idea of the bidirectionality of upbringing and child-parent relations; that is, it views child-parent relationships as containing mutuality and reciprocity in interactions and consequences (De Mol \& Buysse, 2008; Kuczynski, 2003; Kuczynski \& Navara, 2006). Further, interpersonal influence is acknowledged as a process in which both parties influence each other's thoughts, behavior, and emotions (see Alanen, 2003; De Mol \& Buysse, 2008; Kuczynski, 2003; Kuczynski \& Navara, 2006; Kuczynski \& Parkin, 2007). This study draws on ideas from childhood studies as well as sociological, feminist, and psychological studies on family relationships, power, and agency. The aim here is to analyze how young children describe and make sense of parental control and negotiations between children and parents. The participants were 18 Finnish children aged from 4 to 7 . Their accounts, and researcher observations of challenging situations and negotiations between the children and their parents, were collected using a multi-method approach.

\section{Bidirectionality of the Child-Parent Relationship and Children's Agency}

In general, agency is described in terms such as pursuing intentional actions, motivation, will, resilience, choice, initiative, participation, and sense of autonomy and control (see e.g., Bjerke, 2011; Kuczynski, 2003; Kumpulainen, Lipponen, Hilppö, \& Mikkola, 2013; Rainio, 2008; van Nijnatten, 2010, p. 7; Wood, 2013). Greene (2012) argues that children's agency is given multiple meanings, and that, in some sense, confusion exists in the field of childhood studies over how to understand the concept of agency. Here, children's agency is understood as relational and as an ongoing process that is constructed and negotiated in everyday life in interaction with others (Alanen, 2009; Bjerke, 2011; Kuczynski \& Parkin, 2007; Kumpulainen et al., 2013). In this conceptualization, agency embodies not only individual agency but also the collective aspects of agency, meaning agency as membership and participation in shared collaborative social practices (Bjerke, 2011; Rainio, 2008).

Kuczynski (2003) divides agency into three dimensions: autonomy, construction, and action. The most visible and traditionally defined dimension of agency is agency as action or agentic behavior. For example, Giddens defines agency as "to be able to deploy ... a range of causal powers, including that of influencing those deployed by others. Action depends upon 
the capacity of the individual to 'make a difference' to a state of affairs or course of events." (Giddens, 1984, p. 14). Critics argue that such sociological accounts of agency as action do not take into account the more subtle and invisible ways of asserting agency (Morrow, 2003; Rainio, 2008). Conversely, autonomy can be seen as the broadest interpretation of agency and refers to the ability to achieve personal control over one's interactions with the environment (Kuczynski, 2003; van Nijnatten, 2010, p. 7) or to feel that one's behavior is freely chosen and volitional (Deci \& Ryan, 2000). Autonomy is considered a basic human need, and even very young children are capable of resisting perceived threats to their autonomy (Deci \& Ryan, 2000; Kuczynski, 2003).

Agency as construction, in turn, denotes an ability to make sense of experiences and create new meanings for things (De Mol \& Buysse, 2008; Kuczynski, 2003; van Nijnatten, 2010, pp. 8-10). Two appropriate concepts of childhood studies in interpreting agency as autonomy and construction from the child's perspective are those of interpretive reproduction and secondary adjustment (Corsaro, 1997). Corsaro (1997), drawing on Erving Goffmann's theorizations, introduced the concept of secondary adjustment. The concept refers to the idea that people often thought to be in suppressed positions in society (bluecollar workers, in Goffman's case; young children, here), can achieve control over their lives and resist threats to their autonomy by creating subtle or hidden ways of resisting the prevailing norms and rules of the environment. These concepts portray children as active agents who interpret, creatively participate in, mold, and resist aspects of adult culture, such as rules and norms (Corsaro, 1997; also see Löffdahl \& Hägglund, 2006; Punch, 2005), although in conflict situations achieving agency may be challenging for young children.

\section{Asymmetry of the Child-Parent Relationship and Relational Power}

Perceiving children as agents and seeing them as having an impact on how the childparent relationship develops and changes signifies a need to conceptualize power in relational terms (Kuczynski \& Parkin, 2007; Punch, 2005). Alanen (2003, 2009) introduced the concept of generational order, which can be divided into external and internal order. That is, in addition to seeing generation as an external and structural category, it should be approached through contemplating the internal, relational, interactional, and complex connections of children's relations to their social world. In so doing, children's agency can be situated in the analysis of generational order and of child-adult relationships. Alanen (2003) argues that a relational view of generational order entails seeing child-adult relationships as interdependent. For example, in the child-parent relationship an individual in a parental position is dependent on the actions of an individual in the child's position, although the relationship is necessarily asymmetrical in many respects(Alanen, 2003; see also Punch, 2005).

In practice, an external generational order and power asymmetry are readily apparent in the child-parent relationship. In the study by Punch (2005), children also acknowledged the imbalance of power inherent in child-parent relationships. Morrow (2003) argues for understanding structural phenomena as not necessarily determining individual children's experiences, but rather as influencing children by setting the boundaries of what is possible, appropriate, and expected. Further, she emphasizes that children lack the power of authority - the power that is derived from adult status (also Punch, 2005). In this sense, it has also been concluded that children occupy a powerless position in society and within the family context (Jensen, 2003; Morrow, 2003). De Mol and Buysse (2008) also point out that overt 
emphasis on the child-parent relationship context should not cause us to forget the hierarchical position of adults and children in families and in society at large.

Extending these ideas further, the present study applies a relational view and a threefold conceptualization of power, in which three dimensions of power are analytically demerged (Allen, 2002, 2008; Gjerstad, 2009). Power over signifies the ability of an actor or set of actors to constrain the choices available to another actor or set of actors (Allen, 2002, 2008). Power to refers to the ability or capacity to act in spite of or in response to the power wielded over a person by others (Allen, 2002, 2008; Gjerstad, 2009). Power to can be seen to be connected to agency; that is, to an opportunity to resist, to suggest other options, or to participate in the negotiation of power to attain an end (see Allen, 1998; Punch, 2005; Rainio, 2008). It is enabling power, and linked to the idea of empowerment (Allen, 2002, 2008). Power with can be defined as the ability to work in concert (see Allen, 1998, 2002). It is related to co-operation, sharing, and reciprocity, and can be linked to the concepts of participation and sense of belonging (Allen, 1998, 2002; Gjerstad, 2009). Allen (1998) defines power with as a collective ability to act together in order to attain some common or shared end. It may, however, occur for the attainment of bad ends or exist asymmetrically; for example, some members of the family may form coalitions against others (see Allen, 1998).

In the context of the child-parent relationship, power over is generally justified on the grounds that children need to learn the norms and values of adults and society as they grow older (van Nijnatten, 2010). Further, the United Nations' Convention on the Rights of the Child (CRC) states that a child has a right to protection and guidance from adults (Committee on the Rights of the Child, 2006; see also Bjerke, 2011; Lister, 2007; Merry, 2007; Punch, 2005). Thus, parents may assert legitimate authority in carrying out their responsibilities for their children's wellbeing, such as protecting their children from harm or prohibiting them from doing damage; parents can also exercise disciplinary power, by such means as controlling resources (Punch, 2005). Legitimate authority may, however, also turn into a means of controlling, manipulating, subordinating, denying, limiting, or oppressing the child (see Allen, 2008; Punch, 2005).

Compliance on the part of the child has been considered the normal and acceptable response to parental discipline and demands (see Cooper \& Cefai, 2009; De Mol \& Buysse, 2008; Kuczynski, 2003; Rainio, 2008). The use of parental power may result in a situation of not acknowledging the child's agency and not hearing the child's voice. However, children's responses to parental authority vary: they may understand that their parents are wellintentioned, and so acquiesce and comply, but they are also capable of resisting or negotiating with adult and parental authority (see Biesta, 2012a; Kuczynski, 2003; Kuczynski \& Parkin, 2007; Punch, 2005; Wood, 2013). Thus, power struggles and negotiations in the child-parent relationship and care occur on a daily basis and are something parents and children both recognize (Cockburn, 2010; Kuczynski \& Parkin, 2007; Punch, 2005).

According to Kuczynski (2003), children can perform committed, situational, or unwilling compliance. In the case of committed compliance, the activity at hand is in the child's perceived interest, and so the child agrees to comply with or supports the parent's initiative. In the case of situational compliance, the child can perform agentic and creative construction of the situation in question and decide to comply, although this may not be the case on another occasion. Situational or unwilling compliance may also be strategic 
compliance, performed in the hope of achieving more important goals in the future (Kuczynski, 2003; Kuczynski \& Parkin, 2007).

Children's resistance can be defined as acting to oppose perceived threats to one's autonomy or acting contrary to parental wishes; or as participation in decision-making, perhaps by suggesting alternatives or negotiating (Bjerke, 2011; Kuczynski, 2003; Moore, Gegieckas, Marval, McCauley, \& Peloquin, 2011; Rainio, 2008). Resistance by children is often viewed as negative and problematic behavior, signifying disobedience towards adults (Cooper \& Cefai, 2009; Rainio, 2008). However, by those in marginal positions, resistance can also be recognized as a struggle to have a voice, agency, and citizenship (Moore et al., 2011; Rainio, 2008). Thus, resistance can be seen as having transformative potential, as a way of creating an agentic engagement with the world (Biesta, 2012a, 2012b; Rainio, 2008).

Negotiating can be understood as a constructive way of resisting that embodies a dialogical relationship between the parties, as opposed to either withdrawal or destructive resistance (Biesta, 2012a, 2012b). Kuczynski and Parkin (2007) reason that in child-parent confrontations the aim is not so much to achieve compliance, but more often to resolve the conflict by negotiation or accommodation and to thus achieve co-operation. Negotiations can, however, be seen in a more problematic way. Millei (2012) points out that adult guidance and negotiation on children's behavior that are attached to dialogical pedagogy also embody a power aspect, but in a more hidden and implicit manner. Negotiations related to how the child should behave and understand his or her behavior and the consequences of that behavior rather powerfully guide how the child should aim at behaving. Millei (2012) argues that the power dimension of dialogical pedagogy often goes unrecognized (see also Moore et al., 2011; Wood, 2013).

\section{The Present Study}

In this study power is understood as something children and parents construct in their everyday interaction, although the existing external generational order and asymmetry of the child-parent relationship is also taken into account. This is crucial in the present instance, where the aim is to understand how young children see power in the child-parent relationship. By theorizing children's agency as the capacity to resist perceived threats to their autonomy and to influence parents, not only through their actions but also through more subtle modes of resistance, some of the possibilities for, as well as constraints on, young children’s agency are rendered visible (Corsaro, 1997; De Mol \& Buysse, 2008; Kuczynski, 2003).

The present study has three goals. The first is to identify the everyday situations involving power struggles and negotiation that arise in young children's talk. The second is to analyze what dimensions of power are visible in these situations, and the third is to explore what possibilities for children's agency exist in these situations.

\section{Method}

\section{Participants}

The participants for the present study were recruited for a larger research project titled Young children's daily family life and positive parenting, the author's post-doctoral research project, which was funded by the Academy of Finland. The aim of the larger project was to find out, from the perspectives of the different family members, especially those of young 
children, what constitutes a satisfying family life. The participants comprised 18 children from 15 families, six girls and twelve boys, aged from 4 to 7 years. All the children were attending day-care and early childhood education on a daily basis, and none were yet at school (in Finland formal schooling starts in the year of the child's seventh birthday). In addition, 14 mothers, one stepmother and 10 fathers of the children, were also recruited for the project. Parental socio-economic status varied from blue collar through pink collar to highly educated white collar. In many families, mothers had higher educational status than their partners. In two families, the mothers were on parental leave, and two mothers were students in vocational training or on study leave. The present study focuses solely on the children's data.

Recruitment was done through two different procedures: first, by a snowball technique, which yielded six participating families; and second, with permission from the municipality, by meetings in day-care centers attended by both children and parents, which yielded a further nine families. Three of the boys were brothers from the same biological family and two of the children were a brother and a sister from another biological family. The children's family types comprised 12 nuclear families, two one-parent families, and one step-family. In families where the children had siblings, these varied by number and gender. Three of the participants had no siblings. Place of residence ranged from rural and suburban to urban and inner-city areas, located in various parts of Finland.

\section{Data Collection}

Data for the project were collected during two to four visits to the children's homes. It has been argued that a perspective combining several data collection methods, known as a multi-methods approach or mosaic approach, enables a better insight into the complexity and breadth of children's lived experience (Clark, 2005; Einarsdóttir, 2007). All the methods applied in the study shared the same general aim of focusing on daily family life, and most of the methods were task-based, enabling a participatory approach to be used with the children. (For more detailed information see Table 1). Observations and video-recordings of daily family situations and actions, Draw-your-day interviews (Eldén, 2012), and a specific storytelling method called Story Magician’s Play Time (see Laakso \& Turja, 2011) formed the data for the study. Other methods used in the project included a mobile diary, taking photographs, and walking tours, but these did not produce material for the present report.

Story Magician's Play Time. This method produced the highest number of accounts suitable for the present analysis. The method has been developed for listening to young children and combines guided story-telling and play (Laakso \& Turja, 2011). The method is based on the knowledge that young children often describe their everyday experiences in the form of narratives and stories (Laakso \& Turja, 2011; Puroila, Estola, \& Syrjälä, 2012). The point of departure for story-telling is a collection of pictures illustrating habitual daily moments, such as bed-time, coming to eat, being bored, being left out of the peer group, and wanting to buy something (for the collection of pictures, see Appendix A). The instruction for telling a story is: "Here are some pictures of ordinary everyday situations which can happen to all children". The child is then asked to look at the pictures and choose one to tell a story about with the help of prompts designed to facilitate narration: "What has happened in the picture?" "Who are in the picture?" "What has happened earlier in the story?" "What might happen next?" In addition, the child is asked about the emotions experienced by the characters in the story, using questions such as "How does the child feel now?" "How does Mummy or Daddy feel?" Emotions are discussed with the help of emotion cards developed by Pesäpuu (a Finnish child 
protection and welfare league) by asking the child to show and name the emotions the characters are feeling (e.g., sad, angry, happy, satisfied/pleased, afraid, disappointed). The child's story is then played out with various props: story frames, dolls, and furniture (see Appendix B). At the end the child is asked whether she or he has ever been in a similar situation.

The children told one to four stories each. Of the total number of stories 28 were about a power struggle or negotiation (see Table 1). In addition, three boys did not tell stories based on the pictures, but developed stories of their own (six stories). The stories produced were rich and informative about both the child's understanding and construction of the reasons and causes for the course of events in these challenging moments, and how she or he evaluated the protagonist's agentic capacities in attaining his or her goal (see Nicolopoulou, 2008).

Observations and video-recordings. Direct observations by the author were carried out during the morning before the children went to child care and their parents to work (ca. from 6 a.m. to 8 a.m.), and during the afternoon and evening after child care and work (ca. from 4 p.m. to 9 p.m.) in their homes, along with field notes describing what the child was doing and with whom, and the interaction and general atmosphere during these activities. An alternative data collection procedure for the participating families and children was to carry out videorecordings themselves. Here, the instruction was to videotape one meal with the child, bedtime, play-time, and if not present in these, one activity shared by the whole family. The child, together with the whole family, could freely decide when to videotape. If the child so wished, the video recordings were watched and afterwards discussed together. Only two families allowed me to observe their day, and six families made some, but not all, of the requested video recordings. In addition, I wrote field notes after each home visit in order to recall what happened during the visits.

Table 1

Data Collection Methods and Methodological Principles

\begin{tabular}{|c|c|c|c|}
\hline $\begin{array}{l}\text { Data collection } \\
\text { methods }\end{array}$ & Participants & $\begin{array}{l}\text { Data utilized in the } \\
\text { present study }\end{array}$ & Methodological principles \\
\hline $\begin{array}{l}\text { Draw-your-day } \\
\text { interview }\end{array}$ & 12 children & 4 children's interviews & $\begin{array}{l}\text { - Multi-method approach } \\
\text { and use of diverse methods }\end{array}$ \\
\hline $\begin{array}{l}\text { Story Magician } \\
\text { Play Time }\end{array}$ & $\begin{array}{l}17 \text { children (34 } \\
\text { stories) }\end{array}$ & $\begin{array}{l}14 \text { children's stories, } \\
\text { total } 28 \text { stories }\end{array}$ & $\begin{array}{l}\text { Participatory and task- } \\
\text { based methods that allow } \\
\text { the child to be active and }\end{array}$ \\
\hline $\begin{array}{l}\text { Observations and } \\
\text { video-recordings }\end{array}$ & $\begin{array}{l}8 \text { children and } \\
\text { families }\end{array}$ & $\begin{array}{l}\text { one observation and } \\
\text { one video-recording }\end{array}$ & $\begin{array}{l}\text { creative, facilitating young } \\
\text { children’s self-expression } \\
\text { - Voluntariness and choice } \\
\text { - Respect, minimizing the } \\
\text { use of power and the } \\
\text { position of adult authority } \\
\text { - Children's satisfaction }\end{array}$ \\
\hline
\end{tabular}

Note. Methodological principles are from Clark, (2005); Einarsdóttir, (2007); Hill, (2006); Morrow, (2003); and Winter, (2012). 
Draw-your-day interviews. The methodological strengths of interviews with drawing are that for most young children drawing is a familiar activity, and it allows the child to narrate and discuss her or his drawing instead of researcher interpretations of the content of the pictures after the event (Einarsdóttir, 2007). The Draw-your-day method has been developed and used with slightly older children in a Swedish study on children and care (see Eldén, 2012). In Finland, a similar method was developed by Pesäpuu, which has also designed methods for listening to young children's accounts of their daily lives. In this study, specific questions were planned to go with the drawing task. The children were given a large sheet of paper divided into four frames, each for a picture about a different time of day: morning, daytime, evening, and night. The questions asked what an ordinary morning (or afternoon, evening, or night) was like, what had happened, and who the child had been with during the good or bad morning, or what the different family members had been doing that morning. Altogether 12 children performed the drawing task, but a description, always very brief, of a conflict situation occurred in only four cases (e.g., "My father orders me to hurry up in the morning. This is not nice.”)

\section{Data Analysis}

The data were transcribed verbatim in their entirety. The language used to conduct the study was Finnish. The translations into English of the excerpts selected for this report are as far as possible verbatim but, where this impedes understanding, priority is given to preserving the overall meaning. In order to answer the first research question, all the children's stories were analyzed to identify all the episodes demonstrating a recognizable power conflict or struggle and to categorize these by context (see Table 2). Such situations or episodes could be imaginative or they could be reflections of the children's everyday experiences. It is important to note that it was the researcher who identified situations or episodes as a power struggle or a negotiation, not the children. The children themselves neither presented a situation as challenging or conflicting nor used those precise words when talking about the events in question. However, all the children except two described at least one such situation in their materials; one boy and one girl did not describe any power struggle or negotiation situation.

In the closer analysis of the episodes, attention was paid to the course of events and the position, roles, and actions of child and parent, applying the following categories: (a) orientation: the beginning of the situation, focusing on which characters were present and who initiated the actions in the episode; (b) complicated action: the ensuing sequence of events and the other party's response to the initiated actions; and (c) resolution: focusing on which of the participants in the situation needed to change or did change their behavior (Bamberg, 2012; Labov, 1972; Nicolopoulou, 2008; see Table 3). This analysis was done to be able to answer the second and third research questions related to power and children's agency. According to Bamberg (2012), people use narratives to construct their identities by evaluating three sets of binary oppositions: first, sameness versus difference between self and other; second, agency versus passivity or recipiency; and third, consistency versus change across time (see also van Nijnatten, 2010, pp.8-11). In these episodes narrated by children, the first two binary oppositions were dominant. Two approaches were used in analyzing the positions and roles of child and parent. First, attention was paid to whether these roles were evaluated in terms of the sameness of the child and the parent, or the difference between them (Bamberg, 2012). Second, agency versus recipiency was identified by considering whether the child or the adult was the recipient of the other's actions, and considering the child's possibilities for agency (showing initiative or resisting, and freely expressing her or 
his opinions, including the showing of negative emotions) versus compliance (Kuczynski, 2003; Rainio, 2012).

\section{Ethical Issues}

Special attention was paid to ethical issues, as this study involved families and children. In researching children, adults often act as gate-keepers of the children's voices (Morrow, 2005; Powell \& Smith, 2009). This phenomenon was attenuated by meeting all the participants - both children and adults - well beforehand and also by gathering data from both the children's and parents' viewpoints. The families and children were recruited on a voluntary basis and both the children and their parents gave their informed consent. Participants were aware that they were allowed to discontinue their participation in the study at any point. The participants were assured that the information they gave would be handled confidentially and stored in a manner in keeping with the information security demands laid down for research data in Finland. All the names in the article are pseudonyms. The participating families were informed about the dissemination of the research and promised a summary of the findings at the end of the project.

Additional attention was paid to explaining the idea of the research to the children. This demanded time and sensitivity in explaining the aims and procedures of the study in order for them to give their proper informed consent to participate in the research (Morrow, 2005; Powell \& Smith, 2009; Winter, 2012). The children were given a cartoon picture illustrating the research process; this was used to explain the purpose and procedures of the study. The children were informed that they could choose for themselves which tasks they were willing to take part in, that they could tell me when they wanted to end our "session", and that they could freely say if they did not want to continue participating or to perform a certain task (see Winter, 2012). The aim here was to enable the children to have a sense of control over the research process (see Gibbs, MacDougall, \& Harden, 2013; Winter, 2012).

The children's narratives are the outcome of collaboration (Puroila et al., 2012); in this case, that of the child and the researcher. This is an ethical issue in that the researcher has to guard against prompting the child too directly to continue with her or his narration; or, in the case of Story Magician's Play Time, has to be able to follow the child's plot lines, which could project the characters in the story into adventures and denouements rare in adult storytelling or in daily life. Hence, it was important to let the child tell the story as she or he wanted to in order to respect the child's meaning-making process.

\section{Findings}

\section{Power Contexts in Daily Family Life}

The first aim of this study was to identify the kinds of everyday situation that explicitly raised the issue of power in the child-parent relationship. Episodes were selected with the help of sensitizing theoretical concepts under the threefold conceptualization of power discussed above: power over, power to, and power with. Altogether 34 episodes were found that involved an identifiable power struggle, and could be classified according to the context (see Table 2). 
International Journal of Child, Youth and Family Studies (2015) 6(4.1): 622-645

Table 2

Power Contexts in Daily Family Life

\begin{tabular}{l} 
Episodes (number of episodes) \\
\hline Everyday routines and rules \\
Eating and meal times (10) \\
Brushing teeth and bed time (6) \\
Leaving home (in the morning) and wearing of clothes (5) \\
Shopping for groceries (3) \\
Washing dishes (1) \\
Being bored (1) \\
Accomplishments and interests \\
Playing digital games (2) \\
Wishing for a pet (1) \\
Baking (1) \\
Not being allowed to watch TV (1) \\
Playing in the park (1) \\
More general descriptions \\
Being given orders and disobedience \\
(combination of all pictures in the story-telling moments) (2)
\end{tabular}

In the children's accounts, everyday family routines and rules, in particular those related to meal times and eating, were the most frequent context of a power struggle between child and parent (cf. Campos et al., 2013; Kuczynski \& Parkin, 2007; Punch, 2005), whereas such power struggles occurred less frequently in the context of the children's accomplishments and interests. It is nevertheless worth emphasizing that daily routines and rules did not inevitably signify conflict; rather, the children mostly gave accounts of cooperation when talking about their daily family lives. In particular, the routines and rituals related to being tucked in and saying good night, and night awakenings, were not susceptible to power struggle, but instead were described as reciprocal and harmonious.

\section{Dimensions of Power and Agency in the Children's Accounts}

The second and third aims of the study concerned the dimensions of power and the child's possibilities for agency in the children's accounts of power. In Table 3, all the episodes are arranged according to their plot, comprising the three phases of orientation; complicated action, including the child's responses and behavioral change; and resolution. 
Table 3

The Course of Events, Dimensions of Power and Agency in the Power Episodes

\begin{tabular}{|c|c|c|c|c|c|}
\hline Orientation & $\begin{array}{l}\text { Complicated action: } \\
\text { The child's response to } \\
\text { the situation }\end{array}$ & $\begin{array}{l}\text { Resolution: } \\
\text { Change of behaviors }\end{array}$ & $\begin{array}{l}\text { Dimension of } \\
\text { power }\end{array}$ & Child's agency & $\begin{array}{l}\text { Degree of } \\
\text { difference between } \\
\text { the child and adult }\end{array}$ \\
\hline \multirow{3}{*}{$\begin{array}{l}\text { The parent } \\
\text { demands or } \\
\text { requests that the } \\
\text { child act or behave } \\
\text { in a certain way. }\end{array}$} & $\begin{array}{l}\text { The child complies/ } \\
\text { decides to comply/obey. }\end{array}$ & $\begin{array}{l}\text { Parent ends the situation by } \\
\text { parental authority and child } \\
\text { complies. }\end{array}$ & $\begin{array}{l}\text { Adult power over } \\
\text { Power with } \\
\text { Child's power to }\end{array}$ & $\begin{array}{l}\text { Different forms of compliance } \\
\text { Secondary adjustment } \\
\text { Interpretive reproduction }\end{array}$ & High \\
\hline & $\begin{array}{l}\text { The child resists } \\
\text { openly/refuses to act } \\
\text { accordingly. }\end{array}$ & $\begin{array}{l}\text { Parent ends the situation by } \\
\text { parental authority } \\
\text { /reconciliation. }\end{array}$ & $\begin{array}{l}\text { Adult power over } \\
\text { Child's power to } \\
\text { Power with }\end{array}$ & $\begin{array}{l}\text { Resistance } \\
\text { Reconciliation } \\
\text { (compliance) }\end{array}$ & Moderate \\
\hline & $\begin{array}{l}\text { The child resists/refuses } \\
\text { to act accordingly/acts } \\
\text { non-constructively. }\end{array}$ & $\begin{array}{l}\text { The situation proceeds } \\
\text { unchanged, without negotiation } \\
\text { or reconciliation. }\end{array}$ & $\begin{array}{l}\text { Adult power over } \\
\text { Child's power to }\end{array}$ & Resistance & Low \\
\hline \multirow{3}{*}{$\begin{array}{l}\text { The child wants (to } \\
\text { do) something, but } \\
\text { the parent does not } \\
\text { allow it or } \\
\text { disregards the } \\
\text { child's initiative. }\end{array}$} & $\begin{array}{l}\text { The child does not feel } \\
\text { competent as an agent/ } \\
\text { acts secretly. }\end{array}$ & $\begin{array}{l}\text { The situation ends without open } \\
\text { negotiation and reconciliation. }\end{array}$ & $\begin{array}{l}\text { Adult power over } \\
\text { Adult omitting }\end{array}$ & $\begin{array}{l}\text { Compliance } \\
\text { Secondary adjustment }\end{array}$ & High \\
\hline & $\begin{array}{l}\text { The child resists by } \\
\text { continuing to engage in } \\
\text { the forbidden action/ by } \\
\text { being more demanding. }\end{array}$ & $\begin{array}{l}\text { The situation is resolved by } \\
\text { negotiation and/or reconciliation } \\
\text { /the parent changes his/her mind. }\end{array}$ & $\begin{array}{l}\text { Adult power over } \\
\text { Child's power to } \\
\text { Power with }\end{array}$ & $\begin{array}{l}\text { Resistance } \\
\text { Secondary adjustment } \\
\text { Negotiation }\end{array}$ & Moderate \\
\hline & The child negotiates. & $\begin{array}{l}\text { The situation is resolved by } \\
\text { shared negotiation and/or } \\
\text { reconciliation. }\end{array}$ & $\begin{array}{l}\text { Child's power to } \\
\text { Power with }\end{array}$ & $\begin{array}{l}\text { Negotiation } \\
\text { Reconciliation }\end{array}$ & Low \\
\hline
\end{tabular}


When plot was scrutinized in the conflict situations, the orientation phase was quite often an initiative, demand, suggestion, or request from a parent. In most cases, it was the child who needed to change his or her behavior; usually to stop doing something before it was finished, and start doing something else, which might not have been in the child's perceived self-interest. Alternatively, the parent may have suppressed the child's initiative by refusing the child's request to have or do something. The complicated action phase described the differing responses of the child to the situation, such as complying with, supporting, or resisting the adult's suggestion with a counterdemand, a refusal, or by negotiating. The resolution phase, in turn, showed who had the power to institute change and so end the situation (cf. Rainio, 2008).

In the final phase of the analysis, three diverse story types, based on the type of power and the different qualities of the child's agency were identified: (a) adult power over and the child's compliance; (b) the child's power to and resistance; and (c) power with and the child's agency in accommodation. Consequently, in the following sections, the children's accounts are classified according to these three main story lines. Along with the main types, the different subtypes found are also presented.

Adult power over and the child's compliance. Veera, a 5-year-old girl with a mother, a father, and a 7-year-old sister, is talking about a character in a story, Katariina, and her conflict over brushing her teeth. Katariina is asked to stand in the corner after refusing to brush her teeth. I (researcher) ask:

\author{
Researcher: What'd happen next? \\ Veera: [Whispers. On the recording I repeat the words that Veera \\ whispered quietly, which cannot be heard.] Oh, her dad yells, \\ what does he yell at her? \\ Veera: To go and stand in the corner. \\ $\mathrm{R}$ : What does Katariina think about there? \\ $\mathrm{V}$ : She thinks about her manners. \\ $\mathrm{R}$ : Oh, she thinks about her manners. What happens next? \\ $\mathrm{V}$ : She decides to comply after all. \\ (Veera, Family 12, story-telling moment)
}

Setting and enforcing the rules related to sleeping times and brushing one's teeth, eating and meal times, watching TV or playing computer games, and good manners or behavior, was often considered a parental responsibility in these children's accounts. Compliance was detected in the children's accounts when the children showed that they knew and followed the rules in their family. Veera's answer, "She decides to comply after all”, sounds very adult and can be interpreted to mean that she feels it is the right thing to do to think about one's manners and to comply when an adult tells a child to stand in the corner. In many stories, the child's compliance was part of the resolution to the power struggle situation, signifying the child's acknowledgement of the power discrepancy between child and adult.

However, it is important to notice that the children were not simply passive recipients of such parental practices, but also demonstrated agency while complying. Veera, like the other children in the study, constructed compliance as her choice. Veera's choice of the word “decides” stresses children's need to feel a sense of agency and defend their autonomy in a 
situation where compliance is demanded in a domineering manner. Agency need not be a straightforward matter: it may be manifested as creativity in interpretation and construction even when complying, as Corsaro (1997) and Kuczynski (2003) have pointed out.

Child's power to and resistance. In the children's narratives, resistance took a variety of forms from passive noncompliance to non-constructive behavior, blurring the line between resistance and compliance. Action was one typical form of resistance in these young children's narratives. A story told by a 6-year-old boy named Arttu, who is living with his mother, father, and big brother, narrates resistant actions by a boy character he names Lassi and his father's responses. In Arttu's story, the father asks Lassi to brush his teeth, but Lassi refuses. Arttu explains: "Lassi should brush his teeth, but then he goes away, and takes a teddy bear from his bed and runs away.” Lassi's resistance at this stage is physical: running away from his father, and hence the situation. This mode of resistance is partly due to the prompt picture, which shows a child running away with a teddy bear. Running away was also something that all the children who chose this picture found amusing, perhaps because of the openly resistant behavior depicted. Dunn (1988) discusses the amusement evoked by forbidden actions, often present in these young children's narratives.

Later in Arttu's story, as in many other cases, a simple refusal or a verbal objection provided another mode of open resistance: In answer to my question "Well, what does the boy say?” Arttu says “I won’t come.” Normally, verbal objections did not seem effective as a way of resisting the parent, as they often failed to change the adult's mind, the parent continuing to make the same demand. In Arttu's story, the father, disregarding Lassi's objection, "then carries him there [to the bathroom] and brushes his teeth."

A different mode of resisting by an action was to break the set rule either openly or secretly. Lassi chooses the first alternative, when going to the kitchen in Arttu's story:

A: He eats something.

$\mathrm{R}$ : Oh, even if his teeth have been brushed, does he?

A: Yep.

R: Aha. Well, what does his dad think about that?

A: [enthusiastically, not answering my question] Look, he's eating something even though it's evening, he's eating something!

R: Aha. Is he a bit like ha ha, now I'm going to eat, even though you've brushed my teeth?

A: Yeah.

However, the adult was also able to use physical inhibition and power over the child in order to get the child to do as asked, as happens twice in this story, first when his dad is carrying Lassi to the bathroom, and later, when he forbids Lassi to eat after his teeth have been brushed:

$\mathrm{R}$ : What does his dad do then?

A: Then he catches him before he eats.

R: OK. Does he go to bed then? Should...

A: ...And then he puts him to bed. 
Agency as construction is manifested in Arttu's story, where the story character Lassi thinks about the situation: "This is not fun.” I interpret Lassi's (spoken aloud) thought to signify that the child is engaged in active meaning-making, in which, although coerced to comply, the child continues to maintain his opinion regarding the negative nature of the event. A similar process can be traced in the emotions Arttu imagines Lassi experiencing the next morning:

A: Then he falls asleep. Then in the morning [pause], in the morning he is satisfied, happy, glad, sad, angry, and disappointed at the same time.

$\mathrm{R}$ : Then in the morning?

A: Yeah, yes.

Thus, the child is able to connect a variety of emotional meanings to the situation. The creativity of children's thinking and secondary adjustment also become actualized in these imagined story-telling moments. In Arttu's story, this can be seen in Lassi's aim of eating something after his teeth have been brushed, of doing something he knows to be forbidden and irrational. Doing something forbidden and illogical serves as a way of resisting the parent's demand and thus as a demonstration of power over the parent and the situation.

Other children produced similar everyday stories and accounts. In many cases, these children illustrated the idea of passive noncompliance or resistance. Passive resistance is noticeable in Arttu's story, where Lassi is unwilling to reconcile his differences with his dad in the evening. Two other children explained noncompliance as stemming from the child's inability to hear or to listen to what a parent said. For example, Saana, a 6-year-old girl with a baby brother, father, and stepmother, explains her story character's behavior as follows:

Her mother is making breakfast and it's terribly noisy in the house because the girl has a baby brother, who's crying out loud all the time, and then the girl doesn't hear what her mother says, when she asks her to come and have breakfast.... [A]nd then she didn't listen to her dad at all, when she was playing there in the living room.

(Saana, Family 8, story-telling moment)

Thus, the child can oppose the parent's request by not listening to what the parent is saying. However, it might also be the case that when children are immersed in an activity, they simply do not hear adults' requests, and the adult interprets the child's behavior as disobedience or resistance.

A different form of passive resistance, refusal, may manifest at meal times as refusing to eat. This, like the above-mentioned forms of resistance, can be seen in a video-recording in which the whole family, Veeti, his mother, his father, and two older brothers, are gathered together for Sunday dinner. However, Veeti, a five-year-old boy, doesn't like rice, which forms part of the meal:

Veeti says, I don't like rice, but his mother asks him to eat the rice along with the chicken and sauce. She tries to persuade Veeti to eat his rice, but he just plays with his fork and leaves it untouched. Different family members try to persuade Veeti to eat, but the food remains on his plate. As dinner proceeds, the mother applies more pressure, and Veeti eats some rice with his chicken. Then he starts to swing on his chair, and his mother and father, once each, forbid this. One by one, the other family members have 
eaten and risen from the table. Finally, only Veeti and his mother are left at table and Veeti becomes restless. He starts playing with his food. His mother reacts by taking his plate away and putting it in the middle of the table. She then gives him back the plate says, Can you behave properly, this is food, you shouldn't play with it. His father says from the kitchen, You have five minutes to eat, then you will be taken away from the table. The situation ends with Veeti's mother again asking him whether he is going to eat, and when Veeti turns away from the plate, she takes first the plate and then Veeti himself from the table, saying, That's enough, thank you, and Veeti starts to scream, No, noooooo! His mother then says, Please leave the table, you are not allowed to play at the table. Veeti answers, I'm not playing! He grabs at the chair, but his mother leads him away and the video-taped dinner episode ends with the father saying to Veeti's older brother, So dinner's over? to which the brother answers, Yes. Although not openly stated in the video, it can be inferred from the dinner conversations that Veeti has been promised dessert, if he eats the entire main course, but now he goes without.

(Veeti, Family 10, video-recording)

In Veeti's case, not eating stems from his dislike of rice, which was not taken into account. Thus, the adult uses parental authority over the child and tries to compel the child to eat. The power difference between the child and the two adults is obvious, and the child's dislike is not taken seriously. It might also be that his parents are trying to teach Veeti to eat different foods for his own ultimate benefit; however, at the same time, the child is treated as a passive recipient of their joint parental practices, not as an agent with the ability to make agreements and decisions. As a result of the pressure applied, Veeti's resistance grows, leading his mother to resolve the situation using adult domination.

Here, then, the parents, as a power-sharing coalition, had power, and thus control, over the resolution to the situation (see Rainio, 2008). The video does not inform us whether they discussed the course of events later. When we watched and recalled Veeti's videos, Veeti expressed his annoyance at this particular clip, probably because of the humiliation he had felt at the time and would now have to relive, and thus was unwilling to watch the video. His mother, in turn, evaluated the situation solely from the perspective of the child's behavior; she did not reflect on her own or the father's behavior. The situation follows the pattern of top-down influence, where parents are active agents and children passive recipients of parental actions. The child's voice is not heard and his resistance not taken into account.

Non-constructive behavior by the child was the last mode of resistance found in the present data. It occurred only twice: once in a child's story and once in an observation situation (observation diary and my own field notes). During a one-day home observation period in the family of a 5-year-old boy named Sasu, the child used power over the mother on a number of occasions, behaving non-constructively by striking his mother or cursing, for example. The following episode occurs after Sasu, his 2-year-old sister, and his mother have arrived home after work and child care. The father is often at work till early evening.

Sasu switched on the TV and started watching children's programs. At the same time he jumped around and made a noise, went into the kitchen for a drink, and slapped his mum on her bottom on his way back to watch TV. After that, he argued with his little sister, but at 16:53 his mother asked the children to come to the dinner table. She repeated her request to Sasu three times at 17:03, and again three times at 17:07. Sasu continued to watch TV and started an argument with his mother, because he did not want to come to eat. Eventually, he came to the table and started to eat. While the two 
children were eating, their mother and I sat round the table, but were not taking part in the meal. Sasu spilt a lot of salad dressing on his plate, and yelled to his mother that he wanted a napkin. Then he struck the table, said "stupid Mum”, swore, and then he and his sister started to tap on the table. He then went under the table, changed his place at the table, screamed, and crossed the room to hang on an armchair. When he left the table to watch TV, some food remained on his plate. After a while he asked his mother for a clean pair of trousers and changed into them. While Sasu's mother and I had coffee, Sasu came over for cookies, and climbed onto the table three times. After a while, his mother took the cookies away and put pieces of cucumber on the table instead.

(Sasu, Family 4, observation field notes)

Sasu ignored his mother's requests, although she asked him very nicely at first. Later she became irritated and snapped at Sasu and his little sister. During the evening, Sasu behaved wildly, but seemed to be attending to his mother's reactions and trying to see whether he could annoy her. He did things he knew were forbidden on many separate occasions. He also slapped his mother despite his mother's telling him not to. She asked him to stop acting up because of my visit, which might have been one reason for his restless behavior. No other reasons for Sasu's behavior were evident to me; it seemed to be the habitual pattern of interaction between him and his mother (as could also have been the case in Veeti's family, although their interaction pattern was entirely different), and the child's way of putting up rather strong resistance to all his mother's initiatives. The confrontation remained unresolved throughout the evening, as if two equals were continuously engaged in an ineffective struggle over who had power over the other.

\section{Power With and the Child's Agency in Accommodation}

In the power episodes, two types of accommodation - negotiation and reconciliation - were identified. Accommodation pertained to the negotiated nature of power and to the aim of seeking a resolution to the conflict by coming to an agreement. One type of accommodation concerned negotiations about rules. In these situations, rules were discussed and agreed upon by adults and children together, which meant that the children had an opportunity to influence the rules, as was the case in 6-year-old Eetu's story titled "The boy [Jonatan] won't eat":

And his mum comes in: Jonatan, why haven't you eaten your dinner?

Jonatan says: I don't want to, it's bad food.

Mum says: You need to eat it.

Jonatan says: I won't eat, I won't listen to you.

He then puts his hands over his ears.

Mum says: You need to eat it.

Jonatan says: OK, how many spoonfuls do I have to take?

Mum: You need to take three spoonfuls, three times.

Jonatan says: OK. Three spoonfuls of smashed potatoes, meatballs three, three spoonfuls of salad and three tomatoes.

OK, now Jonatan eats everything [smacks his lips], and says: this food was really quite good. 
Mum says: All right, now you can have dessert.

Jonatan says: Thank you, bye-bye.

Now he goes to his room. The end.

(Eetu, Family 2, story-telling moment)

Thus, in Eetu's story, as in the other children's accounts, the child participated in the decision-making and negotiated to resolve the power-struggle situation, although the orientation of the situation is that of parental authority and the child's compliance. Jonatan, in the story, after making a verbal objection and saying he will not listen to his mother, initiates the resolution to the conflict by negotiating.

Another example of negotiation concerns a shopping expedition. I had asked Arttu if any situations like those shown in the prompt pictures had happened to him. He immediately recalled an incident from a couple of days before. He had found a toy car in the supermarket and wanted it, but his father refused. Arttu had cried and he told me that after shopping his father took him and his brother for ice cream. Here, the father's behavior could be seen either as setting necessary constraints to the child's agency, or as exercising power over the boy's will and initiative. However, when I next visited the family, there had been a sequel to the incident. Arttu had brought up the issue again and negotiated permission to buy the car with his own weekly pocket money. Thus, he had been active and persistent in his demand and persuaded his parents to change their minds about the toy. The example clearly shows how a child is able to negotiate and the negotiable nature of power.

Reconciliations were frequent in the children's stories. When the children were asked to think about how both the adult and the child could end up happy, such reconciliations were sometimes child-initiated, and the child ended the story with an apology initiated by the child character. Thus, the children recognized the cultural script or pattern of what constitutes decent and appropriate (and compliant) behavior in a situation that has been characterized by disobedience and conflict (cf. Millei, 2012). Consequently, the children were able to, and did, reflect on their own "bad" behavior, whereas the adults did not usually reflect on their behavior. However, it was also common for the child to suggest that the adult needed to be the one proposing reconciliation or that both the child and the adult should apologize equally.

\section{Discussion}

This study investigated power in child-parent relationships and young children's possibilities for agency in power-struggle situations. In the children's accounts, everyday family routines and rules most often formed the context of the power struggles between child and parent. Campos and her colleagues (2013), Kuczynski and Parkin (2007), and Punch (2005) have yielded comparable findings. The power episodes were divided, according to their plot, into three different types: compliance, resistance, and accommodation.

Importantly, in the children's accounts three different dimensions of power were identified: (a) power over, parental authority that requires the child's compliance and obedience; (b) power to, the power of resistance; and (c) power with, negotiation and reconciliation. However, many episodes did not follow these ideal structures. In most episodes resistance was but one component of the child's agency within the complicated action, while the resolution involved either compliance or accommodation.

These children's thoughts about complying seem to cohere with the general idea that parents have, and need to have, the legitimate authority and power to set the rules and the 
right to use their power in daily family routines (see Cooper \& Cefai, 2009; De Mol \& Buysse, 2008; Kuczynski, 2003; Punch, 2005; Rainio, 2008). The child's part was then one of complying with these rules. However, when complying, the children utilized their agentic capabilities in terms of interpretive reproduction and construction by identifying diverse emotions, including negative ones, and making sense of the conflict situation in ways that preserved a mental space for their own agency (cf. Kuczynski, 2003; Nicolopoulou, 2008; Rainio, 2008). Overall, while both the external and internal generational order, and the children's dependence on their parents and lack of power, were clearly visible in the children's data, these were nevertheless negotiated, resisted, and challenged, as well as overturned, in the interaction between child and parent (see Alanen, 2009; DeMol \& Buysse, 2008; Morrow, 2003).

In the confrontation between child and adult, whether in the child's story or as observed behavior, their roles as a power user clearly differed. From the perspective of power, the adults certainly had the advantage; however, the children showed an ability to oppose the adults' demands in various and creative ways, demonstrating their deployment of agency and the power to influence the course of events. From the perspective of children's agency, the children's decisions to resist parental authority showed them to be active agents, interpreting, creatively participating in, and shaping the rules and norms of adult culture (Corsaro, 1997). Applying Kuczynski’s (2003) division of agency into autonomy, construction, and action helped to differentiate the forms of resistance in the children's accounts. Children's agency was manifested in their resistance, either open or veiled, towards threats to their autonomy and towards restrictions and parental control over their agentic behavior. This resistance could, as already stated, be covert or overt, and it could also be verbal or non-verbal, and constructive or non-constructive, such as physically acting out. When accommodating, the children both utilized their agentic skills not only by negotiating and being aware of the implicit rules of reconciliation but also, when they considered the adults responsible for the challenging situation, by positioning the adult as the party to make the apology and initiate reconciliation. When power to is defined as the ability to act in spite of or in response to the power wielded over a person by others (Allen, 2002, 2008), then it can be seen as connected to agency: to an opportunity to oppose, to suggest other options, or to participate in the negotiation of power to attain an end or series of ends (see Allen, 1998; Biesta, 2012a, 2012b; Moore et al., 2011; Punch, 2005; Rainio, 2008).

Earlier studies with slightly older children have emphasized children's capacity to influence adults and parents, and to make shared decisions and negotiate with adults, but have also identified challenges faced by children (Bjerke, 2011; De Mol \& Buysse, 2008; Punch, 2005). It can be argued that children's agency and dependency both need to be seen as inevitable parts of the intertwined nature of the child-parent relationship, in which children can both express their agency yet also continue to be dependent on care, protection, and guidance from parents (see Bjerke, 2011; Kuczynski, 2003; Lister, 2007; Punch, 2005; van Nijnatten, 2010, pp. 33-35). In other words, it ought to be possible for the child to "engage with what resists” (in Biesta's phrase), which signifies a dialogical relationship between child and parent (Biesta, 2012a; 2012b).

\section{Limitations and Future Research}

A possible criticism of this study is the relationship it implies between these young children's narrated stories and their lived experiences. However, in narrating stories, we show how we understand, make sense of, and evaluate events (Labov, 1972; Nicolopoulou, 2008; 
Puroila et al., 2012; van Nijnatten, 2010, pp. 8-10). Story-telling can be seen as a way of broadening a child's understanding of the meaning of events and of the role of personal agency in influencing and finding solutions to challenging events and experiences (Bennett, 2008; van Nijnatten, 2010, pp. 8-10). Viewed in this light, the method applied here might not produce the "truth" about a given course of events, but it enables children to envisage experiences familiar to them from their daily child-parent conflicts in a way not threatening to their emotional security or loyalty towards their parents, and which enables them to rehearse their agency in influencing and finding solutions (see Bennett, 2008). The observational data and Draw-your-day interviews did not produce such tidy endings, complete with reconciliation, as the stories. Instead the situations remained either unresolved or the resolution was parental power over, demonstrating both the persisting nature of such confrontational situations and their significance for the child-parent relationship and for young children's possibilities for agency. Parent's intentions and explanations were not a focus of the present study, and thus the interpretations do not give a complete picture of the child-parent power-struggle situations presented. Also, gendered aspects of power conflict and negotiations were not considered; a further study taking child and parent gender into account might produce additional information and perspectives on power and agency in the child-parent relationship. Finally, the observation by Punch (2005) that family relationships, including power struggles, are also a place for love, care, and positive affection was largely borne out in the stories told by the children in this study.

\section{Conclusions}

Parents may have good reasons for imposing limits on their children in the name of protecting and raising them. This study, however, showed that parents often guide rather powerfully how the child should aim at behaving, or they offer an overdetermined scaffolding that rules out constructive dialogue (cf. Millei, 2012; Moore et al., 2011, van Nijnatten, 2010, pp. 33-35; Wood, 2013). Hence, the most important question is the theoretical dilemma related to the nature of child-parent relationships and upbringing, namely, to what extent can children and parents (adults) be considered equals, and to what extent are parents (adults) morally justified in using power over to restrict their children's agentic behavior. That is to say, what are the necessary constraints on children's agency (see Greene, 2012; Rainio, 2008)? Biesta (2012a, 2012b) argues for a stance towards raising children that understands resistance as a force that connects children with the world. To protect children from harming themselves or others, and to help them internalize societal and socially necessary rules, children's behavior and agency can be restricted, just as adults are in the face of laws and societal and social rules (see van Nijnatten, 2010). It then becomes important to ask in what ways should such restriction be carried out, and whether the restricting and structuring of their lives suitably takes children into account as agents and as thinking and feeling individuals, whose opinions, likes and dislikes, feelings, and moods need to be taken seriously, and to whom justifications and explanations should be given for the rules and restrictions imposed on them (see Cooper \& Cefai, 2009; Moore et al., 2011; Punch, 2005; Rainio, 2008; van Nijnatten, 2010, pp. 33-34). The issue at stake is whether adults, in interacting with and bringing up children, see and hear them through sameness or difference, as agents or as the targets and recipients of parental or adult practices. It is not only related to the internal generational order, but also affects and feeds the external order (see Alanen, 2003, 2009). This is fundamentally an ethical question and decision. 
International Journal of Child, Youth and Family Studies (2015) 6(4.1): 622-645

\section{References}

Alanen, L. (2003). Childhoods: the generational ordering of social relations. In B. Mayall \& H. Zeiher (Eds.), Childhood in generational perspective (pp. 27-45). London, UK: University of London: Institute of Education.

Alanen, L. (2009). Generational order. In J. Qvortrup, W. A. Corsaro, \& M.-S. Honig (Eds.), The Palgrave Handbook of Childhood Studies (pp. 159-174). Basingstoke, UK: Palgrave Macmillan. http://dx.doi.org/10.1057/9780230274686

Allen, A. (1998). Rethinking power. Hypatia, 13, 21-40. http://dx.doi.org/10.1111/j.1527-2001.1998.tb01350.x

Allen, A. (2002). Power, subjectivity and agency: Between Arendt and Foucault. International Journal of Philosophical Studies, 10, 131-149. http://dx.doi.org/10.1080/09672550210121432

Allen, A. (2008). Power and the politics of difference: Oppression, empowerment, and transnational justice. Hypatia, 23, 156-172. http://dx.doi.org/10.1111/j.1527-2001.2008.tb01210.x

Bamberg, M. (2012). Why narrative? Narrative Inquiry, 22, 202-210. http://dx.doi.org/10.1075/ni.22.1.16bam

Bennett, L. (2008). Narrative methods and children: Theoretical explanations and practical issues. Journal of Child and Adolescent Psychiatric Nursing, 21, 13-23. http://dx.doi.org/10.1111/j.1744-6171.2008.00125.x

Biesta, G. (2012a). The educational significance of the experience of resistance: Schooling and the dialogue between child and world. Other Education: The Journal of Educational Alternatives, 1, 92-103.

Biesta, G. (2012b). Giving teaching back to education: Responding to the disappearance of the teacher. Phenomenology \& Practice, 6, 35-49.

Bjerke, H. (2011). 'It's the way they do it': Expressions of agency in child-adult relations at home and school. Children \& Society, 25, 93-103. http://dx.doi.org/10.1111/j.1099-0860.2009.00266.x

Campos, B., Plaksina, T., Repetti, R. L., Ochs, E., Wang, S., Schoebi, D., \& Beck, M. E. (2013). Positive and negative emotion in the daily life of dual-earner couples with children. Journal of Family Psychology, 27, 76-85. http://dx.doi.org/10.1037/a0031413

Clark, A. (2005). Listening to and involving young children: A review of research and practice. Early Child Development and Care, 175, 489-505. http://dx.doi.org/10.1080/03004430500131288

Cockburn. T. (2010). Children and the feminist ethic of care. Childhood, 12, 71-89. http://dx.doi.org/10.1177/0907568205049893

Committee on the rights of the child. (2006). Recommendations after the day of general discussion on the right of the child to be heard. Geneva, Switzerland: Committee on the rights of the child.

Cooper, P., \& Cefai, C. (2009). Contemporary values and social context: Implications for the emotional wellbeing of children. Emotional and Behavioural Difficulties, 14, 91-100. http://dx.doi.org/10.1080/13632750902921856

Corsaro, W. (1997). The sociology of childhood. Thousand Oaks, CA: Pine Forge Press.

Deci, E. L., \& Ryan, R. M. (2000). The "what" and "why" of goal pursuits: Human needs and the self-determination of behavior. Psychological Inquiry: An International Journal for Advancement of Psychological Theory, 11, 227-268. http://dx.doi.org/10.1207/s15327965pli1104_01 
De Mol, J., \& Buysse, A. (2008). The phenomenology of children's influence on parents. Journal of Family Therapy, 30, 163-193. http://dx.doi.org/10.1111/j.1467-6427.2008.00424.x

Dunn, J. (1988). Beginnings of social understanding. Oxford, UK: Basil Blackwell. 59/harvard.97806743

Einarsdóttir, J. (2007). Research with children: Methodological and ethical challenges. 30610.fm European Early Childhood Education Research Journal, 15, 197-211. http://dx.doi.org/10.108 $0 / 13502930701321477$

Eldén, S. (2012). Inviting the messy: Drawing methods and 'children’s voices'. Childhood, 20, 66-81. http://dx.doi.org/10.1177/0907568212447243

Gibbs, L., MacDougall, C., \& Harden, J. (2013). Development of an ethical methodology for post-bushfire research with children. Health Sociology Review, 22, 114-123. http://dx.doi.org/10.5172/hesr.2013.22.2.114

Giddens, A. (1984). The constitution of society: Outline of the theory of structuration. Cambridge, UK: Polity.

Gjerstad, E. (2009). Valta kotikasvatuksessa [The use of power in bringing up children at home]. [Research Report 225]. Helsinki, Finland: University of Helsinki. Department of Education.

Greene, S. (2012). Children's agency: Some questions about theory and practice. Lecture in LaNKa-seminar 28.11.2012, University of Jyvaskyla, Jyväskylä, Finland.

Hill, M. (2006). Children’s voices on ways of having a voice: Children’s and young people’s perspectives on methods used in research and consultation. Childhood, 13, 69-89. http://dx.doi.org/10.1177/0907568206059972

Jensen, A.-M. (2003). For the children's sake: symbolic power lost? In A.-M. Jensen \& L. McKee, (Eds.), Children and the changing family. Between transformation and negotiation (pp. 134-148). London, UK: Routledge. http://dx.doi.org/10.4324/9780203451823

Kuczynski, L. (2003). Beyond bidirectionality: Bilateral conceptual frameworks for understanding dynamics in parent-child relations. In L. Kuczynski (Ed.), Handbook of dynamics in parent-child relations (pp. 3-46). Thousand Oaks, CA: Sage. http://dx.doi.org/10.4

Kuczynski, L., \& Navara, G. S. (2006). Sources of innovation and change in socialization, internalization and acculturation. In M. Killen \& J. Smetana (Eds.), Handbook of moral development (reprinted 2010, pp. 299-327). New York, NY: Psychology Press. http://dx.doi.org/10.4 $324 / 9781410615336$

Kuczynski, L., \& Parkin, C. M. (2007). Agency and bidirectionality in socialization: Interactions, transactions, and relational dialectics. In J. E. Grusec \& P. Hastings (Eds.), Handbook of socialization (pp. 259-283). New York, NY: Guilford Press.

Kumpulainen, K., Lipponen, L., Hilppö, J., \& Mikkola, A. (2013). Building on the positive in children's lives: A co-participatory study on the social construction of children's sense of agency. Early Child Development and Care, 184(2), 1-19. doi:10.1080/03004430.2013.778253.

Laakso, M.-L., \& Turja, L. (2011). Tarinataikurituokiot - menetelmä ylivilkkaiden ja haastavasti käyttäytyvien lasten kokemusten kuulemiseen osana kuntoutuskäytäntöä. [Story Magican's Play Time - A method for listening to overactive and challenging behaving children's experiences as a part of occupational practice.] In E. Aalto, M. Alasuutari, T. Heino, T. Lamponen, \& N. Rutanen (Eds.), Suojeltu lapsuus? Raportti lapsuuden-tutkimuksen päiviltä 2011 (pp. 77-79). [Raportteja 51]. Helsinki, Finland: Terveyden ja hyvinvoinnin laitos. 
Labov, W. (1972). Language in the inner city: Studies in the black English vernacular. Oxford, UK: Blackwell.

Lister, R. (2007). Why citizenship: Where, when and how children? Theoretical Inquiries in Law, 8, 693-718. http://dx.doi.org/10.2202/1565-3404.1165

Löffdahl, A., \& Hägglund, S. (2006). Power and participation: Social representations among children in preschool. Social Psychology of Education, 9, 179-194. http://dx.doi.org/10.100

7/s11218-006-0002-8

Merry, M. S. (2007). The well-being of children, the limits of paternalism, and the state: Can disparate interest be reconciled? Ethics and Education, 2, 39-59. http://dx.doi.org/10.108 $0 / 17449640701284909$

Millei, Z. (2012). Thinking differently about guidance: Power, children’s autonomy and democratic environments. Journal of Early Childhood Research, 10, 88-99. http://dx.doi.org/10.117

Moore, S. A., Gegieckas, T., Marval, L., McCauley, H., \& Peloquin, S. (2011). Constructing critical citizenship with young people: Alternative pedagogies. International Journal of Child, Youth and Family Studies, 3 \& 4, 494-509.

Morrow, V. (2003). Perspectives on children's agency within families: A view from the sociology of childhood. In L. Kuczynski (Ed.), Handbook of dynamics in parent-child relations (pp. 109-131). Thousand Oaks, CA: Sage. http://dx.doi.org/10.4135/9781452229645

Morrow, V. (2005). Ethical issues in collaborative research with children. In A. Farrell (Ed.), Ethical research with children (pp. 150-165). Maidenhead, UK: Open University Press.

Nicolopoulou, A. (2008). The elementary forms of narrative coherence in young children's storytelling. Narrative Inquiry, 18, 299-325. http://dx.doi.org/10.1075/ni.18.1.07nic

Powell, M., \& Smith, A. (2009). Children’s participation rights in research. Childhood, 16, 124-142. http://dx.doi.org/10.1177/0907568208101694

Punch, S. (2005). The generationing of power: A comparison of child-parent and sibling relations. Sociological Studies of Children and Youth, 10, 169-188. http://dx.doi.org/10.1016/ s1537-4661(04)10009-3

Puroila, A.-M., Estola, E., \& Syrjälä, L. (2012). Does Santa exist? Children’s everyday narratives as dynamic meeting places in a day care centre context. Early Child Development and Care, 182, 191-206. http://dx.doi.org/10.1080/03004430.2010.549942

Rainio, A. P. (2008). From resistance to involvement: Examining agency and control in a playworld activity. Mind, Culture and Activity, 15, 115-140. http://dx.doi.org/10.108 0/10749030801970494

van Nijnatten, C. (2010). Children's agency, children's welfare: A dialogical approach to child development, policy and practice. Bristol, UK: Policy Press. http://dx.doi.org/10.1332/policy press/9781847424891.001.000

Winter, K. (2012). Ascertaining the perspectives of young children in care: Case studies in the use of reality boxes. Children \& Society, 26, 368-380. http://dx.doi.org/10.1111/j. 1099-0860.2010.00335.x

Wood, E. A. (2013). Free choice and free play in early childhood education: Troubling the discourse. International Journal of Early Years Education [Published online]. doi:10.1080/09669760.2013.830562. 
International Journal of Child, Youth and Family Studies (2015) 6(4.1): 622-645

\section{Appendix A}

The collection of pictures for Story Magician’s Play Time

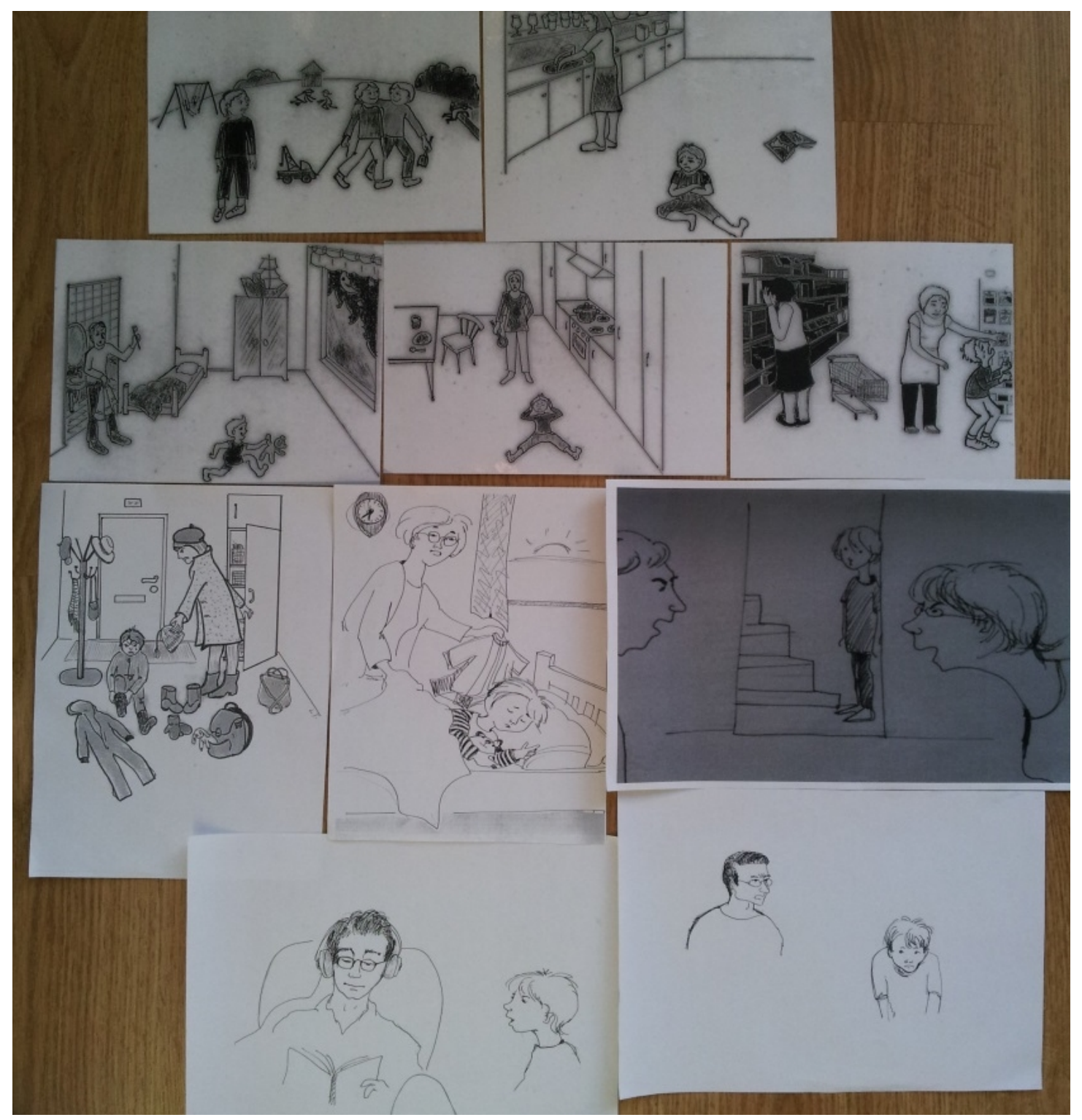


International Journal of Child, Youth and Family Studies (2015) 6(4.1): 622-645

\section{Appendix B}

Story prompts for Story Magician’s Play Time

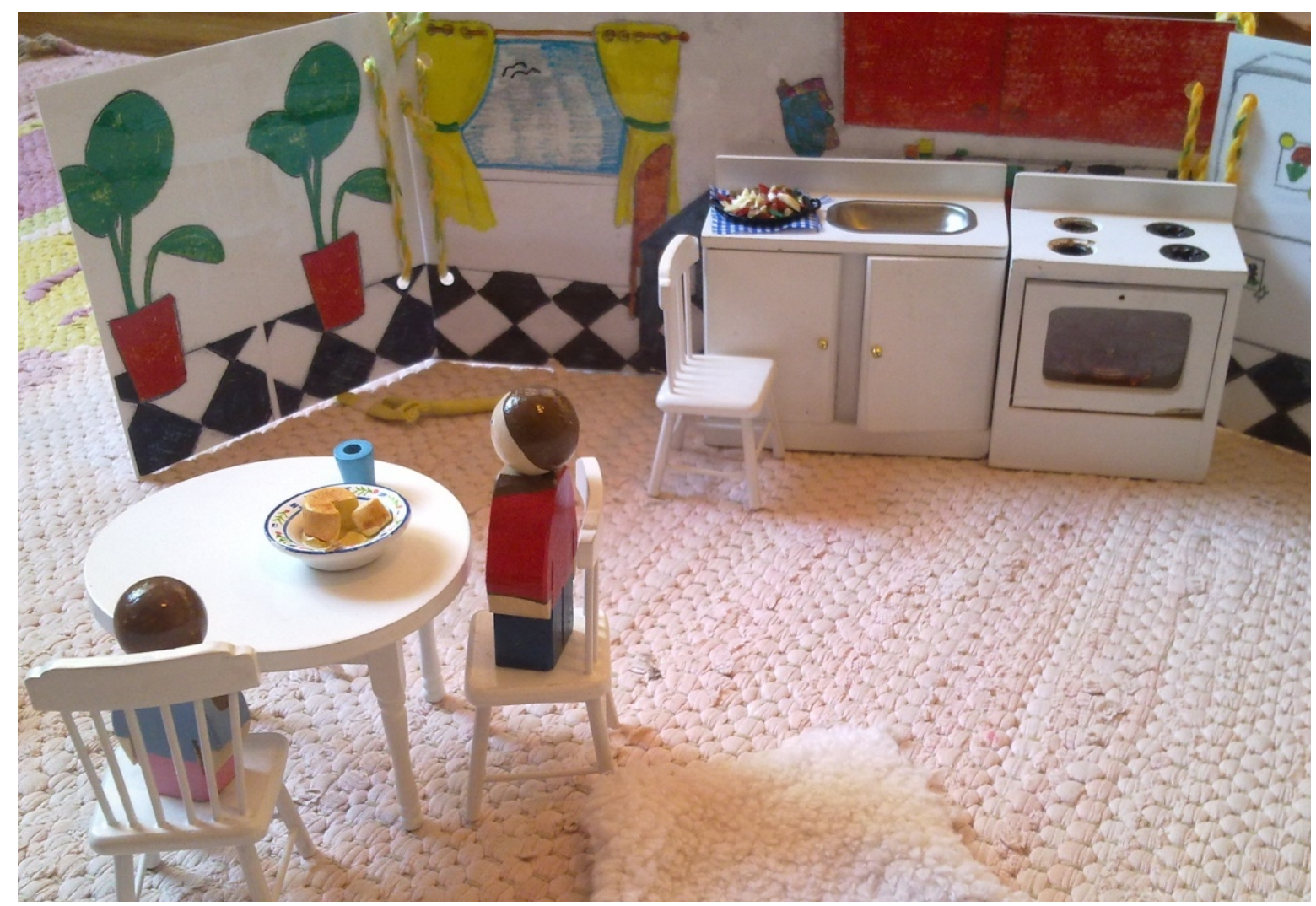

